\title{
ANALISIS KEBUTUHAN PENGEMBANGAN MODEL PEMBELAJARAN BBM3 UNTUK MENINGKATKAN METAKOGNISI MAHASISWA
}

\author{
Andi Suhandi ${ }^{*}$, Issaura Sherly Pamela \\ Program Studi Pendidikan Guru Sekolah Dasar, Fakultas Keguruan dan IImu \\ Pendidikan, Universitas Jambi, Muaro Jambi, 36361, Indonesia \\ "andi.suhandi@unja.ac.id
}

\begin{abstract}
This study aims to analyze the needs of developing BBM3 learning models (Thinking, Planning, Implementing, Monitoring, Evaluating) to improve student metacognition. The research is conduct by survey method in the Elementary School Teacher Education Study Program (PGSD), Teacher Training and Education Faculty (FKIP), Jambi University. The research subjects were $1153 \mathrm{rd}$ semester students and 4 PGSD lecturers. The objects studied were curriculum analysis of PGSD FKIP UNJA, students' metacognition abilities, the learning process that has been applied so far especially in improving student metacognition, and lecturers' and students' responses to the development of BBM3 learning models. The research instruments used to obtain data were questionnaires and tests. Data obtained from these instruments were analyzed descriptively. The analysis results obtained are the PGSD FKIP curriculum in UNJA demanding students think about thinking, known as metacognition, not all lecturers invite students to monitor and evaluate learning continuously. The class average of the students' metacognition ability tests was in the poor category with a score of 32.87. The learning process so far has focused on improving teaching skills in elementary schools, activeness, and student character, not all lecturers have explored metacognition abilities, with the category sometimes. Lecturers interested in the BBM3 learning model with the category of strongly agree. The conclusion of this research is the need for the development of BBM3 learning is very high, so this learning model needs to be developed.
\end{abstract}

Keywords: learning model, BBM3, student metacognition

\section{PENDAHULUAN}

Istilah metakognisi berarti Kognisi tentang fenomena kognitif, atau lebih sederhana berpikir tentang berpikir (Lai, 2011). Metakognisi secara luas didefinisikan sebagai pengetahuan atau aktivitas kognitif yang melihat dan mengatur objek atau setiap aspek melalui usaha kognitif (Flavell, 2002). Flavell dalam Jonassen (2011) membedakan dua karakteristik metakognisi, yaitu: 
pengetahuan tentang kognisi dan regulasi tentang kognisi. Pengetahuan tentang kognisi meliputi: a) declarative knowledge, b) procedural knowledge, c) conditional knowledge sedangkan regulasi tentang kognisi meliputi: a) planning, b) information management strategies, c) comprehension monitoring, d) debugging strategies, dan e) evaluation. Pengetahuan tentang kognisi mencakup pengetahuan tentang variabel tugas, strategi, dan pribadi. Artinya, pengetahuan metakognisi meliputi pengetahuan dari keterampilan yang dibutuhkan oleh tugas yang berbeda, pengetahuan strategis (pengetahuan tentang strategi pembelajaran alternatif dan kapan harus menggunakannya) dan pengetahuan diri (pengetahuan tentang kemampuan seseorang dan kemampuan orang lain). Regulasi kognisi mencakup kemampuan untuk memonitor pemahaman seseorang dan mengendalikan kegiatan belajar seseorang.

Metakognisi sering dihubungkan dengan merencanakan, memantau, dan mengevaluasi serta memperbaiki tindakan yang telah dilakukan. Keterampilan metakognisi pasti dimiliki setiap mahasiswa, namun setiap mahasiswa memiliki kemterampilan yang berbeda-beda. Saat proses pembelajaran berlangsung keterampilan metakognisi dapat dikembangkan menjadi lebih baik. Sebelum mampu menerapkan metakognisinya untuk membantu proses pembelajaran, terlebih dahulu mereka diajarkan strategi-strategi untuk menilai pemahaman mereka sendiri, menghitung berapa waktu yang mereka perlukan untuk mempelajari sesuatu, dan memilih rencana yang efektif untuk belajar.

Keterampilan metakognisi dapat dikembangkan dengan berbagai cara, salah satunya adalah mengajarkan mahasiswa dengan model pembelajaran yang tepat. Model pembelajaran adalah suatu acuan kepada suatu pendekatan pembelajaran termasuk tujuannya, sintaknya, lingkungannya, dan sistem pengolahannya (Slavin, 2010). Eggan (2012) model pembelajaran adalah strategi perspektif pembelajaran yang didesain untuk mencapai tujuan-tujuan pembelajaran tertentu. Model pembelajaran yang telah ada saat ini banyak yang mendukung untuk mengembangkan keterampilan metakognisi mahasiswa namun masih terdapat keterbatasan dan kelemahannya. Jika menggunakan model PBL, kelemahannya adalah mahasiswa yang tidak berniat untuk memecahkan masalah akan malas untuk belajar, waktu yang dibutuhkan cukup lama, dan tidak semua 
mahasiswa berusaha untuk memecahkan masalah dengan maksimal. Jika pembelajaran menggunakan model inkuiri maka keterbatasanya adalah sulit mengontrol kegiatan dan keberhasilan mahasiswa, waktu yang dibutuhkan lama. Pada umumnya mahasiswa memerlukan waktu yang lama untuk beradaptasi dengan model pembelajaran yang diterapkan.

Berdasarkan hasil observasi di Program Studi PGSD FKIP Universitas Jambi mahasiswa yang diajarkan dengan model PBL memerlukan waktu yang lama untuk beradaptasi dan memecahkan masalah yang diberikan selain itu penelitian sebelumnya menerapkan strategi Taccasu Project mahasiswa masih kewalahan dengan lamanya waktu yang dibutuhkan namun hasil metakognisi mahasiwa yang diperoleh membaik. Mengembangkan keterampilan metakognisi mahasiswa dengan efisiensi waktu yang tepat sampai saat ini masih menjadi masalah. Waktu yang dibutuhkan mahasiswa memilih strategi yang tepat dan mampu diterapkan serta sesuai dengan materi IPA sangat lama sehingga mahasiswa yang menyelesaikan dengan cepat merasa bosan menunggu kelamaan.

Berdasarkan uraian yang telah dikemukakan, maka peneliti akan melalukah kajian tentang "Analisis Kebutuhan Pengembangan Model Pembelajaran BBM3 untuk Meningkatkan Metakognisi Mahasiswa".

\section{METODE PENELITIAN}

Penelitian ini lebih memusatkan perhatian pada analisis tentang pentingnya pengembangan model pembelajaran BBM3 untuk meningkatkan metakognisi mahasiswa. Penelitian ini merupakan bagian dari grand desain yang berjudul "Pengembangan Model Pembelajaran BBM3 untuk Meningkatkan Metakognisi Mahasiswa" yang menggunakan desain Research and Development (R\&D) (Borg \& Gall, 2004).

Analisis yang dilakukan adalah analisis kurikulum pada materi Pendidikan IPA di SD karena nanti pada materi ini mahasiswa akan di tes kemampuan metakognisinya, analisis karakteristik peserta didik, yang dilakukan melalui tes kemampuan metakognisi, terdiri dari 5 butir pertanyaan mengenai materi mata kuliah Pendidikan IPA di SD, dan analisis kebutuhan pengembangan, yang 
dilakukan melalui angkat kepada dosen dan mahasiswa. Subjek penelitian ini adalah mahasiswa dan dosen PGSD.

Instrumen yang digunakan untuk mengumpulkan data, angket untuk desen dan mahasiswa dan tes untuk metakognisi mahasiswa. Untuk menganalisis data penelitian, digunakan teknik analisis deskriptif.

\section{HASIL PENELITIAN}

Hasil analisis kurikulum: pada tahap ini peneliti mengkaji kurikulum Program Studi Pendidikan Guru Sekolah Dasar (PGSD) FKIP UNJA, pada kurikulum PGSD terdapat mata kuliah Pendidikan IPA di SD. Mata kuliah ini menuntut mahasiswa untuk mengetahui hakikat IPA di SD, mengkaji landasan filosofis dan psikologis mendasari pembelajaran IPA di SD, prinsip dasar pembelajaran IPA SD, mengkaji berbagai pendekatan, strategi, model, metode, dan teknik pembelajaran yang mendidik pada bidang IPA, membuat evaluasi untuk pembelajaran IPA SD, berlatih mengembangkan RPP untuk praktek mengajar, bersimulasi mengajar di kelas. Berdasarkan kompetensi satu semester maka mahasiswa dituntut untuk memiliki kemamapuan metakognisi yang baik agar mampu memiliki pengetahuan yang baik dan memanajemen diri sendiri. Maka perlu adanya model pembelajaran yang mendorong mahasiswa untuk memahami materi dan menigkatkan metakognisi mahasiswa.

Hasil karakteristik peserta didik diperoleh melalui tes kemampuan metakognisi peserta didik. Rata-rata kemampuan metakognisi yang diperoleh sebesar 32,87 yang terletak pada kategori kurang. Hal ini terlihat pada gambar 1 . Dari 115 mahaiswa yang diberikan tes, hanya 1 yang medapatkan nilai 60, terdapat 44 orang yang nilainya 40 , terdapat 56 orang nilainya 30 , dan 11 orang nilainya 20. 


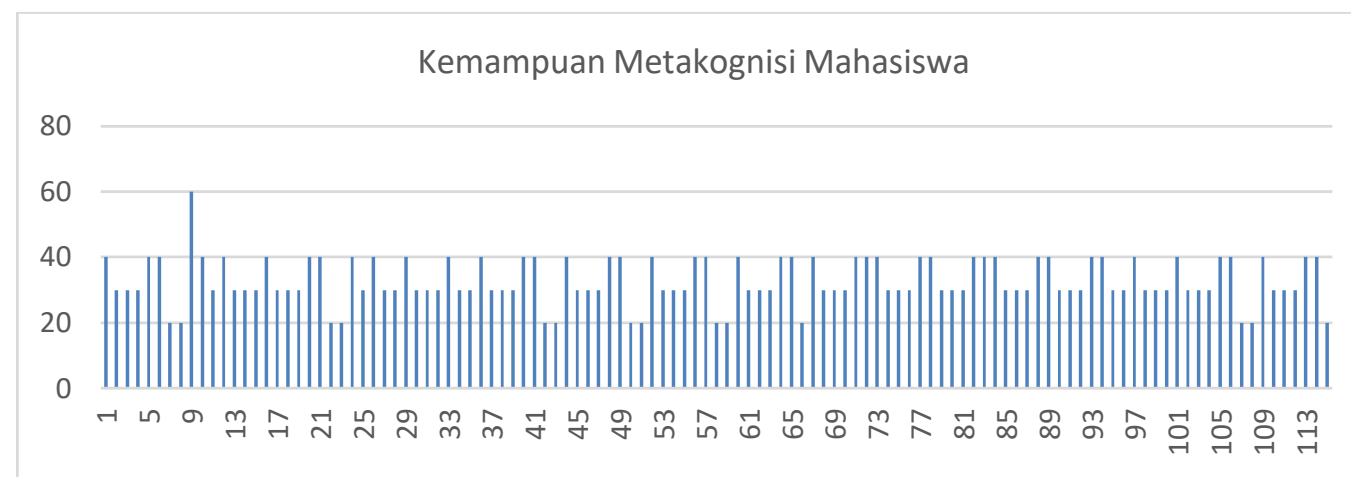

Gambar 1. Hasil Kemampuan Metakognisi Mahasiswa

Hasil analisis kebutuhan dilihat melalui angket proses pembelajaran di kelas dan tanggapan terhadap pengembangan model pembelajaran BBM3. Berdasarkan hasil angket proses pembelajaran di kelas dapat dilihat pada gambar 2.

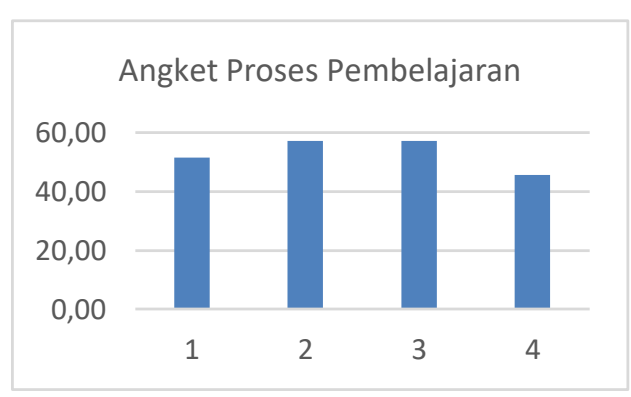

Gambar 2. Angket Proses Pembelajaran di Kelas

Gambar 2 menunjukan keempat dosen berada pada kategori kadangkadang pada semua butir item angket, yaitu: saya meminta mahasiswa untuk merencanakan kegiatan 15x pertemuan perkuliahan, saya meminta mahasiswa berpikir mengenai, hal-hal apa saja yang berkaitan dengan materi seminggu sebelum materi dibahas, saya meminta mahasiswa berencana mengenai, penyelesaian materi seminggu sebelum materi dibahas, saya mengajak mahasiswa menerapkan perencanaan pada buku jurnal individu seminggu sebelum materi dibahas, saya mengajak mahasiswa untuk memikirkan kembali jawaban yang diberikannya setiap pertemuan, saya mengajak mahasiswa merefleksikan hasil pembelajaran yang belum dan telah dicapai setiap pertemuan, saya mengajak mahasiswa untuk mengevaluasi proses pembelajaran setiap pertemuan. 
Hasil angket tanggapan terhadap pengembangan model pembelajaran BBM3 dapat dilihat pada gambar 3

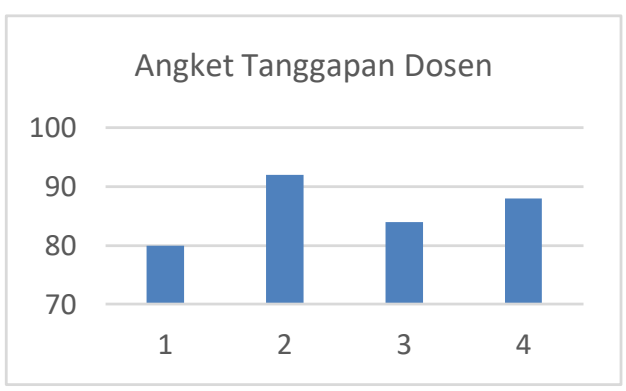

Gambar 3. Angket Tanggapan Dosen terhadap Pengembangan Model Pembelajaran BBM3

Gambar 3 menunjukan ketertarikan dosen terhadap pengembangan model pembelajaran BBM3. Nilai yang diperoleh dari ketiga dosen berada pada kategori sangat setuju dan satu dosen menyetakan setuju. Dari setiap butir item pernyataan, yaitu: tahapan dalam model pembelajaran BBM3 dibutuhkan untuk mencapai tujuan pembelajaran, tahapan dalam model pembelajaran BBM3 dapat meningkatkan metakognisi, tahapan dalam model pembelajaran BBM3 dapat dilakukan sesuai urutan, saya tertarik untuk menerapkan model pembelajaran BBM3, tahapan dalam model pembelajaran BBM3 mudah mengakomodasikan materi pembelajaran.

\section{PEMBAHASAN}

Berdasarkan hasil penelitian analisis kurikulum, kompetensi yang harus dicapai selama satu semester menuntut mahasiswa memiliki kemampuan metakognisi yang baik. Selain tingginya kemamapuan metakognisi, pada tahap ini juga ditentukan bahan ajar dan media yang akan dikembangkan untuk mendukung pembelajaran.

Hasil tes kemampuan metakognisi dengan rata-rata 32,87 merupakan hasil yang kurang baik. Melalui hasil analisis karakeristik ini maka perlu dikembangkan model pembelajaran BBM3. Kemampuan metakognisi yang tinggi akan mudah untuk menyelesaikan masalah dalam pembelajaran. hal ini sejalan dengan hasil penelitian Sholihah (2016) tentang metakognisi merupakan kesadaran dalam 
berpikir, sehingga mengetahui tugas-tugas yang diberikan dan mampu mengontrol apa yang akan dilakukan.

Hasil metakognisi dapat berkembang dengan latihan yang berkelanjutan. Hal ini didukung oleh hasil penelitian Murti (2011) yaitu metakognisi berkembang seiring usia dan dipengaruhi juga oleh latihan. Interaksi satu sama lain dapat memberikan stimulus yang diperlukan oleh individu untuk menjadi lebih menyadari proses kognitif mereka.

Hasil analisis angket proses pembelajaran di kelas menunjukan kepedulian dosen dalam meningkatkan metakognisi masih kurang. Kegiatan yang meningkatkan metakognisi kadang-kadang dilakukan dalam proses pembelajaran. sehingga perlu adanya pengembangan model pembelajaran yang dapat meningkatkan metakognisi dalam pembelajaran di kelas. Pentingnya pengembagan model pembelajaran sejalan dengan hasil penelitian Mariati (2012) tentang pengembangan model pembelajaran fisika berbasis problem solving untuk meningkatkan kemampuan metakognisi dan pemahaman konsep mahasiswa. Mariati mengatakan bahwa kemampuan metakognisi dan pemahaman konsep merupakan kemampuan yang harus dimiliki mahasiswa sehingga mahasiswa mampu mengkonstruksi pengetahuan, mengaplikasikan konsep-konsep fisika, dan memperdalam konsep-konsep fisika yang melahirkan jawaban ilmiah yang mempresentasikan pemahaman. Penelitian Huda dan Umam (2018) mendukung tentang pentingnya model pembelajaran dalam meningkatkan kognisi.

Hasil analisis tanggapan dosen terhadap pengembangan model pembelajaran BBM3 menunjukan rasa ketertarikan yang tinggi untuk menerapkan model pembelajaran BBM3 nantinya. Sehingga berdasarkan hasisl analisis ini pengembagan model pembelajaran BBM3 untuk meningkatkan hasil metakognisi mahasiswa perlu untuk dikembangkan.

\section{SIMPULAN}

Berdasarkan hasil penelitian dan pembahasan analisis kurikulum, analsis karkteristik mahasiswa, dan analisis kebutuhan perlu dilakukannya pengembangan model pembelajaran BBM3 untuk meningkatkan metakognisi mahasiswa dapat disimpulkan sebagai berikut: (1) kurikulum PGSD FKIP UNJA 
menuntut mahasiswa berpkir tentang berpikir yang dikenal dengan metakognisi, tidak semua dosen mengajak mahasiswa untuk memantau dan mengevaluasi pembelajaran secara kontinu, (2) hasil rata-rata kelas tes kemampuan metakognisi mahasiswa berada pada kategori kurang dengan nilai 32,87 selama ini proses pembelajaran fokus pada meningkatkan kemampuan mengajar di SD, keaktifan, dan karakter mahasiswa, belum semua dosen menggali kemampuan metakognisi,dengan kategori kadang-kadang (4) dosen tertarik pada model pembelajaran BBM3 dengan kategori sangat setuju Implikasinya, pengembangan model pembelajaran BBM3 adalah program strategis untuk dilakukan.

\section{DAFTAR PUSTAKA}

Abidin, Y. 2014. Desain Sistem Pembelajaran Dalam Dalam Konteks Kurikulum 2013. Bandung: Refika Aditama.

Arikunto, S. 2003. Prosedur Penelitian, Suatu Praktek. Jakarta: Bina Aksara

Eggan. 2012. Strategi dan Model Pembelajaran. Terjemahan Wahono, edisi keenam, Indeks, Jakarta.

Eleonora Papaleontiou-Louca. 2008. Metacognition and Theory of Mind. Cambridge Scholars Publishing: UK

Gredler, Margaret. E., 2001. Learning and Instruction Teori dan Apilkasi, edisi keenam, Terjemahan Y. Miaso. Jakarta: Kencana.

Hergenhahn dan Olson. 2008. Teori Belajar, edisi ketujuh, Terjemahan Wibowo, Jakarta: Kencana

Huda dan Umam. 2018. Keefektifan Model Problem Based Learning dalam Meningkatkan Hasil Belajar Matematika Kelas V SDIT Az-Zahra Demak. Jurnal Tunjuk Ajar, Volume 1, Nomor 2, 2018

Jonassen, David. 2011. Learning to Solve Problems A Handbook for Designing Problem-Solving Learning Environments. New York: Routledge

Joyce, B, et, al. 2015. Models of Teaching (Ninth Edition). New York: Person Education Inc

Lai. 2011. Metacognition: A Literature Review. New York: Person

Mariati. 2012. tentang pengembangan model pembelajaran fisika berbasis problem solving untuk meningkatkan kemampuan metakognisi dan pemahaman konsep mahasiswa.

Murti. 2011. Metakognisi dan Theory of Mind (ToM). Jurnal Psikologi Pitutur. Volume I, No 2, Juni 2011.

Reigeluth, C. M. 1999. Instructional Design Theories and Models. Mahwah, NJ: Erlbaum

Santrock, J. 2010. Psikologi Pendidikan, edisi kedua, Terjemahan Wibowo. Jakarta: Kencana.

Sholihah, U. 2016. Membangun Metakognisi Siswa dalam Memecahkan Masalah Matamatika. Ta'allum Vol. 04. No. 01 Juni 2016 
Solso R. L, dkk. 2008. Psikologi Kognitif. Terjemahan Rahardanto, M dan Butuadji, K. Edisi kedelapan. Jakarta: Erlangga.

Veenman, dkk. 2006. Metacognition and Learning: Conceptual and Methodological Considerations. Metacognition Learning 2006 1: 3-14 